\title{
Soybean Farming Income between Cooperators and Non-Cooperators during Farmer Field School Program in Central Lombok - Indonesia
}

\author{
Sylvia Kusumaputri Utami ${ }^{*}$, Mardiana Mardiana, Nani Herawati, Baiq Nurul Hidayah \\ Institute for Assessment of Agricultural Technology (Balai Pengkajian Teknologi Pertanian), West \\ Nusa Tenggara Province 83371 Indonesia
}

\begin{abstract}
Soybean is one of the strategic commodities in Indonesia. Demand of soybean continues to increase every year but not followed by adequate supply. In order to increase soybean production, apart from being driven from technical aspects, it is also necessary to pay attention to farmer participation. The aimed of this study were to examine differences in income of the cooperator and non-cooperator farmers during farmer field school (FFS) program and to measure level of technology applied by cooperator farmers in Central Lombok Regency, Indonesia. Numbers of respondents in this study were 26 farmers who were taken by purposive sampling. The research used quantitative method using Benefit Cost (B/C) ratio analysis to calculate the feasibility of farming and scoring analysis to measure the level of technology applied. The results showed that there was a difference in income between co-operator and non-co-operator farmers. The $\mathrm{B} / \mathrm{C}$ ratios of the two farmer groups indicated that feasibility value were 1.22 and 0.87 for cooperators and non-cooperators, respectively. Those values mean that farming in the FFS program was profitable to implement, while non FFS farming was still feasible but have not provided benefits. The level of technology applied by co-operators was still in the medium category.
\end{abstract}

\section{Introduction}

Soybean farming is one of the alternative activities for farmers in order to optimize their land. However, to carry out farming activities, it is important to pay attention to aspects related to the farming itself. The area of paddy fields cultivated by farmers will determine the amount of production that will be obtained by farmers, so that it affects the income that will be received by farmers.

Local soybeans were originally a superior product, but because they competed with imports, the number of farmers who grow soybeans decreased [1]. In addition, the price of local soybeans is very low because it follows the price of imported soybeans. Moreover, soybean productivity which tends to be low due to the lack of use of technology has caused farmers to start leaving farming this commodity.

\footnotetext{
* Corresponding author: sylviakutami@,gmail.com
} 
There are several things that can be the cause of the slow adoption of technology by farmers, including the farmers' doubts about the level of success of the technology or the absence of a location-specific soybean production technology [2].

The common cropping pattern in Central Lombok Regency is rice-grain-not planted. Soybean crop maintenance in this area is still not optimal because it is considered as a side plant. Soybean farmers in this area generally grow soybeans with a spread system, does not estimate the number of seeds used. The seeds used are from uncertified seeds. The fertilizer used is not optimal because it still relies on fertilizer from the rice fertilization in the previous planting so that plant growth is not optimum.

One of the efforts to increase soybean production and farmers' income is the introduction of technology, including the application of Farmers Field School (FFS) program. By following the FFS program, farmers can implement more appropriate planting methods and better use of inputs of seeds, fertilizers, pesticides and labor, which is closer to the recommendations of extension workers [3].

Farmers' incomes are generally influenced by several components, namely the amount of production, selling prices, and costs incurred by farmers in their farming activities. Farmers are required to be careful in studying price developments as a solution in making choices, whether farmers decide to sell or hold their products.

This study aimed to examine differences in income of the cooperator and noncooperator farmers during farmer field school (FFS) program and to measure level of technology applied by cooperator farmers in Segala Anyar Village, Central Lombok Regency, West Nusa Tenggara Province of Indonesia.

\section{Methodology}

\subsection{Data Collection Approaches and Techniques}

The research was conducted using a survey method with observation and interview techniques. The data collected were primary and secondary data. Primary data were obtained from respondent farmers by means of direct interviews assisted by a list of questions that had been prepared. The secondary data were obtained from the service or related agencies related to research.

The technique of determining the number of samples using the Random Sampling method where each farmer has the same opportunity to be selected, farmers who take part in the FFS program were selected randomly, the selected number of samples is 13 cooperative farmers and 13 non-cooperative farmers.

\subsection{Data and Analysis Method}

To find out the purpose of the first study using financial analysis by means of data obtained from respondents who were guided by questions or questionnaires were collected and then tabulated and analyzed, the second used financial analysis by means of data obtained were analyzed tabulated which included revenue costs, income, profits, and R/C Ratio.

\subsubsection{Income Analysis}

To calculate income, the formula used was:

$$
\pi=T R-T C
$$

Where, $\pi$ was Income (IDR), TR was Total Revenue (IDR), and TC was Total Cost (IDR). 


\subsubsection{R/C Ratio Analysis}

To determine the feasibility of soybean farming, $\mathrm{R} / \mathrm{C}$ ratio analysis was used which is a comparison between revenue and cost, namely:

$$
R / C \text { Ratio }=\frac{T R}{T C}
$$

Where, R/C Ratio was Revenue Cost Ratio, TR (Total Revenue) was Total Revenue (IDR), TC (Total Cost) was Total Production Cost (IDR).

\subsubsection{Scoring Analysis of Application Technology}

Determination the level of technology application was measuring by scoring analysis. The maximum score was obtained by multiplying the highest score (5) with the number of question items from each technology component. The minimum score was obtained by multiplying the lowest score (1) with the number of question items. The total score of each respondent was obtained by adding up the scores obtained from each quetion and divided into three categories: low, medium, and high.

\section{Results and Discussion}

\subsection{Existing Condition of Soybean Farming in Central Lombok}

Soybean farmers in Segala Anyar Village, Central Lombok Regency generally grow soybeans in the second planting season after rice. Soybeans are a common crop grown in Dry Season (DS) I on rainfed land by relying on water from residual rainwater. Soil processing systems commonly used by farmers are system without tillage (no tillage). The application of the no tillage planting system in rainfed rice fields can not only speed up planting time but also save production costs. The use of soybean seeds is quite high in this area because the method of planting is still using the spread method without spacing. The need for seeds can reach up to $75 \mathrm{~kg} / \mathrm{ha}$. The New Improved Soybean Varieties is still rarely used. Farmers generally use seeds purchased from the market or use seeds from those planted in the previous growing season. Because soybean farming is still considered only a by-product, most farmers do not carry out maintenance on their plants.

Soybean seeds are only spread on the land without fertilization or weeding, and water sources rely on rainwater. Nutrient needs for plants are expected to be obtained from residual fertilizer residues in the previous season's rice plants. This causes the production of soybeans to be relatively low, ranging from 0.4-0.6 ton/ha. To maintain soil moisture and suppress weed development, soybean farmers in this area utilize rice straw from the previous planting season. To harvest soybeans, farmers generally harvest by cutting soybeans at the base of the stem.

Previous research in Central Lombok Regency stated that farmers planting soybean after rice planting season is over. In addition, farmers who have large areas of land generally plant soybean with spread system because it is requires less labour than the single system so that costs can be minimized [4].

\subsection{Soybean Farming Income and Feasibility Analysis}

Soybean farming is often associated as a dry land crop with low fertility, so that farmers' cultivation methods are generally still minimal, which results in minimal productivity [5]. Soybean farmers face many limitations in the application of technology, such as the use of 
new improved seeds, fertilization, irrigation, pest control, harvest and post-harvest handling. The low application of technology can indeed minimize production costs but also has an impact on low productivity. The application of introduction technology led to an increase in costs caused by increased production costs, labor and capital interest. In addition, this increase in costs was then compensated by additional revenue from increased productivity [6].

\subsection{Farming Fee Structure}

Costs for soybean farming activities of FFS program in Central Lombok Regency consist of costs for seeds, fertilizers, pesticides, labour, land rent, and other costs. Complete data on costs, revenues, income and $\mathrm{R} / \mathrm{C}$ in soybean farming activities during FFS can be seen in Table 1. It is shows that the total cost of soybean farming in FFS Program was IDR $3,373,618$ with the largest cost used for labour of IDR $2,192,380$ or $64.99 \%$ of the total cost. As for the treatment in the use of labour for the management of soybean farming, among others, for seeding, land preparation, planting, weeding, irrigation, and harvesting. The cost structure of FFS soybean farming activities in Central Lombok Regency can be seen in Table 1.

Table 1. The cost structure of FFS soybean farming activities in West Nusa Tenggara Province

\begin{tabular}{|l|r|c|r|r|r|r|r|r|}
\hline \multirow{2}{*}{ Description } & Value & Unit & $\begin{array}{c}\text { Price } \\
\text { per unit } \\
\text { (IDR) }\end{array}$ & $\begin{array}{c}\text { Total } \\
\text { (IDR) }\end{array}$ & Value & Unit & $\begin{array}{c}\text { Price per } \\
\text { unit } \\
\text { (IDR) }\end{array}$ & $\begin{array}{r}\text { Total } \\
\text { (IDR) }\end{array}$ \\
\cline { 2 - 10 } & $1,101.26$ & $\mathrm{~kg}$ & 6,800 & $7,488,730$ & 672.05 & $\mathrm{~kg}$ & 6,731 & $4,523,685$ \\
\hline Production & & & & $3,373,618$ & & & & $2,420,953$ \\
\hline Cost & 63.30 & $\mathrm{~kg}$ & 12,846 & 813,165 & 58.69 & $\mathrm{~kg}$ & 12,598 & 739,308 \\
\hline Seed & & & & 110,971 & & & & 73,126 \\
\hline Fertilizer & 12.82 & $\mathrm{~kg}$ & 2,000 & 25,641 & 11.79 & $\mathrm{~kg}$ & 2,500 & 29,487 \\
\hline NPK & 5.43 & $\mathrm{~kg}$ & 2,131 & 11,574 & & & & \\
\hline Urea & 1.00 & Unit & 73,756 & 73,756 & 1.00 & Unit & 43,639 & 43,639 \\
\hline Others & 1.00 & pack & 257,103 & 257,103 & 1.00 & pack & 180,468 & 180,468 \\
\hline Pesticides & & & & $2,192,380$ & & & & $1,428,051$ \\
\hline Labour & 3.08 & Day & 30,000 & 92,304 & 2.28 & Day & 30,000 & 68,491 \\
\hline $\begin{array}{l}\text { Land } \\
\text { preparation }\end{array}$ & 3.82 & Day & 36,479 & 139,215 & 4.57 & Day & 30,673 & 140,286 \\
\hline Water channel & 9.25 & Day & 31,849 & 294,482 & 3.16 & Day & 30,541 & 96,453 \\
\hline Sowing & 4.84 & Day & 31,768 & 153,616 & 2.99 & Day & 30,000 & 89,675 \\
\hline Fertilizing & 6.98 & Day & 28,899 & 201,847 & 5.00 & Day & 30,000 & 150,000 \\
\hline Weeding & 4.63 & Day & 29,834 & 138,267 & 4.79 & Day & 30,803 & 147,500 \\
\hline Mulching & 3.62 & Day & 33,527 & 121,469 & 2.93 & Day & 30,000 & 87,751 \\
\hline $\begin{array}{l}\text { Pest and } \\
\text { disease } \\
\text { control }\end{array}$ & 15.04 & Day & 31,796 & 478,203 & 10.95 & Day & 28,700 & 314,167 \\
\hline Harvest & 5.32 & Day & 30,868 & 164,185 & 3.08 & Day & 31,500 & 96,953 \\
\hline Drying & 5.29 & Day & 41,908 & 221,617 & 4.90 & Day & 39,499 & 193,521 \\
\hline Threshing & 3.68 & Day & 50,930 & 187,174 & 0.99 & Day & 43,772 & 43,254 \\
\hline Transportation & & & & & & &
\end{tabular}

\subsection{Farming Income and Profitability}

The amount of income obtained by farmers is strongly influenced by the amount of production produced by farmers and the selling price, the higher the production and selling price, the greater the income that will be obtained by farmers. The average production 
produced by respondent farmers in soybean FFS activities in WNT Province in one growing season was $1,101.26 \mathrm{~kg} /$ ha with an average selling price of IDR 6,800 while the average income obtained by farmers was IDR 7,488,730/ha/season. This income is the gross income received by farmers where production costs have not been taken into account.

Farming income is the difference between revenue and all costs or in other words, income includes gross income or total revenue and net income. Gross income or total revenue is the total production value of agricultural commodities before deducting production costs. Net income is income minus production costs. From the calculation results it is known that the net income obtained by farmers who participate in FFS activities in WNT Province was IDR 4,115,112 per planting season per ha. The income of farmers participating in FFS soybean farming in WNT Province can be seen in Table 2.

Table 2. Soybean farming income between cooperator and non-cooperator during Farmer Field School program in West Nusa Tenggara Province

\begin{tabular}{|l|r|r|}
\hline \multicolumn{1}{|c|}{ Description } & Cooperator & \multicolumn{1}{c|}{ Non-cooperator } \\
\hline Revenue (IDR/ha) & $7,488,730$ & $4,523,685$ \\
\hline Cost (IDR/ha) & $3,373,618$ & $2,519,449$ \\
\hline Income (IDR) & $4,115,112$ & $2,004,236$ \\
\hline R/C Ratio & 2.22 & 1.80 \\
\hline B/C Ratio & 1.22 & 0.80 \\
\hline
\end{tabular}

\subsection{Application of Technology to FFS on Soybean Farming}

Table 3. Scoring of application of technological components during FFS program in Segala Anyar Village, Central Lombok Regency, West Nusa Tenggara Province

\begin{tabular}{|c|l|c|ccc|c|c|}
\hline No & \multicolumn{1}{|c|}{ Description } & Score & \multicolumn{4}{|c|}{ Interval } & Category \\
\hline A & Land preparation & 131 & 42 & - & 98 & Low & Moderate \\
& & & 98,1 & - & 154 & Moderate & \\
\hline B & Use of new improved & 215 & 70 & - & 163,3 & Low & Moderate \\
& varieties & & 163,4 & - & 256,7 & Moderate & \\
& & & 256,8 & - & 350 & High & \\
\hline C & Sowing & 128 & 56 & - & 130,7 & Low & Low \\
& & & 130,8 & - & 205,3 & Moderate & \\
\hline D & Fertilization & 74 & 28,4 & - & 650 & High & \\
& & & 65,4 & - & 102,7 & Moderate & Moderate \\
& & & 102,8 & - & 140 & High & \\
\hline E & Use of straw mulch & 154 & 42 & - & 98 & Low & High \\
& & & 98,1 & - & 154 & Moderate & \\
\hline F & Irrigation & 73 & 28 & - & 65,3 & Low & Moderate \\
& & & 65,4 & - & 102,7 & Moderate & \\
& & & 102,8 & - & 140 & High & \\
\hline G & Pest and disease control & 208 & 70 & - & 163,3 & Low & Moderate \\
& & & 163,4 & - & 256,7 & Moderate & \\
& & & 256,8 & - & 350 & High & \\
\hline H & Weeding & 42 & 14 & - & 32,7 & Low & Moderate \\
& & & 32,8 & - & 51,3 & Moderate & \\
& & & 51,4 & - & 70 & High & \\
\hline I & Harvest & 223 & 56 & - & 130,7 & Low & High \\
& & & 130,8 & - & 205,3 & Moderate & \\
& & & 205,4 & - & 280 & High & \\
\hline
\end{tabular}


The recommended soybean farming technology generally cannot be directly applied or adopted by farmers because an innovation takes time to be introduced until it is adopted by farmers. In addition, the speed of adoption of innovation by a person is influenced by many factors, including: age, education level, farm income level, and size of land area, land ownership status, community attitude/prestige, sources of agricultural information used, and a person's level of life.

Based on Table 4, it was known that from 9 technology components that applied in FFS Soybean Activities in Central Lombok, 6 technology components were in the medium category, 2 technology components were in high category, and 1 technology component was in the low category. It was stated that factors influenced farmers' decisions to adopt technology that was the direct benefits provided from the technology delivered, the suitability of technology to socio-cultural values, farming methods and habits, the complexity of technology application, and farmers' perceptions of influence of media/information received by farmers [7].

\subsubsection{Land Preparation}

In the preparation of land for planting soybeans, generally the land used for rice cultivation is not tilled. The application of the no tillage planting system is often used by farmers for grain crops which are usually carried out after rice harvesting. The no tillage system in soybean farming can reduce production costs, thus providing opportunities for greater profits. One of the elements in soybean production technology is the construction of drainage channels, the condition of rainfed land and dry soil, most soybean farmers in Segala Anyar Village did not apply technology in the form of making drainage channels on the land.

\subsubsection{Use of New Improved Varieties}

The level of technology application of respondent farmers based on the use of new improved varieties for some farmers has implemented, as well as in using the number of seeds, some have been as recommended, but in the use of fungicides on seeds before planting, not many have applied. Deliberately stored first to meet the needs of seeds for the next growing season, not the result of buying from seed breeders in the form of labeled seeds. Research in Southeast Sulawesi resulted that the causes of the low level of use of quality seeds at the farmer level, namely the limited availability of certified seeds, the high price of quality seeds, and the lack of understanding of farmers in the use of quality seeds [8]. Overall the level of application of new improved seed technology is in the medium category. The easiest technology adoption for farmers is from components of new improved varieties with higher productivity. However, the adoption of new improved varieties is often hampered by the unavailability of seeds, due to the undeveloped soybean seed industry [9].

\subsubsection{Seed Sowing}

Generally, soybean farmers in Segala Anyar Village, Central Lombok Regency are still low in the application of seed sowing technology. The recommendation for sowing is done by sowing at a depth of 2-3 cm. Some farmers growing soybean by just spreading the seeds without sowingthem in the holes. This causes the use of seeds that should be 2-3 seeds per hole becomes difficult to apply. In addition, the sowing system by spreading causes the plants to have no spacing. The score on this sowing technology is in the low category. One 
of the factors that causes the low application of this technology is because sowing soybeans in a single way requires more labour so that it affects the farming costs incurred.

\subsubsection{Fertilization}

Fertilization activities in soybean farming are generally carried out 2 times, namely during planting and after planting. The recommended dose of fertilizer used is: NPK $100 \mathrm{~kg} / \mathrm{ha}+$ liquid fertilizer 1 liter/ha, but not widely applied by farmers. The level of application of technology with indicators of balanced fertilizer use is in the medium category. This is because the price of fertilizer is still perceived as expensive by farmers so that they do not use the recommended amount of fertilizer. Farmers generally spread fertilizer so that the amount of fertilizer given is not evenly distributed. Thedoses and timing of fertilizer application is also not in accordance with the recommendations. Another research in Tasikmalaya Regency, West Java stated that the cause of the low application rate of fertilization and the cost of fertilizer in soybean farming is because the use of straw as a cover for planting holes can also act as compost [10].

\subsubsection{Use of Straw Mulch}

The use of straw mulch serves to reduce the frequency of weeding, maintain soil moisture, and suppress seed fly attacks. Generally soybeans are planted during DS I or after rice harvest so that farmers are common to use rice straw as mulch for soybean crops. Straw is given by spreading it evenly throughout the plant area. The use of straw mulch belongs to the high category.

\subsubsection{Irrigation}

Water supply and water regulation for soybean planting are still not good. This is because soybean planting in dry land or dry fields only depends on rainfall, while for planting in paddy fields the regulation of water needs is faced with the problem of limited water flow. At the beginning of vegetative growth at 15-21 days after sowing (DAS), during flowering (28-37 DAS), and when filling pods (55-70 DAS) while on dry land it was adjusted to rainfall.

\subsubsection{Pest and Disease Control}

Pest and disease control activities can be carried out in two ways, by using chemicals (chemical pesticides) or by using bio-pesticides. Plant protection efforts carried out by farmers are still limited, most farmers carry out pest and disease eradication after attacks on plants appeared. Pests that often attack soybeans at the site of activity are the pod borer. Yield loss due to pod borer attack can reach $80 \%$, even total loss if no control measures are taken [11].

\subsubsection{Weeding}

Weeding carried out by farmers is quite varied, between $1-3$ times weeding, depending on the number of weeds that grow. Weeding can be done using sickles, hoes, or herbicides. The application of weeding technology is still in the moderate category. Generally, existing soybean farmers in Central Lombok rarely do weeding. In the FFS program, farmers are guided to do weeding according to the number of weeds that grow. Other research revealed 
that weeding treatment on soybean plants can affect the dry weight of the pods produced so that their weight can be heavier than soybean plants without weed control [12].

\subsubsection{Harvest}

Appropriate harvest handling can affect the quality of crop yields. Harvesting too early can cause many young seeds to become wrinkled in dry conditions and easily damaged during storage. Most of the farmers have carried out harvesting technology well, it is shown that the level of technology application is in the high category. Harvesting is done by cutting the base of the stem, when the seeds are ripe or $95 \%$ of the pods are brown/black and most of the leaves on the plant have fallen off.

\section{Conclusion}

The results of technology adoption for soybean FFS participants in WNT Province are still moderate due to the lack of optimal counseling carried out and conventional farming methods for participating farmers. Farmer's income on soybean FFS activities in WNT Province is quite high reached IDR 4,115,112 per planting season per ha and including farming that is feasible because the R/C Ratio value is more than 1 , which is 2.22 . The prospect of soybean farming in FFS activities in the WNT Province has quite a positive impact on farmers' income although the adoption of technology has not been implemented optimally. The application of technology in soybean farming is still in the moderate category.

\section{References}

1. A. M. Marito, F. E. Prasmatiwi, A. Nugraha. Jurnal Ilmu Ilmu Agribisnis, Vol. 2 No. 4 (2014).

2. N. Tjetjep. Prosiding Seminar Nasional. Pusat Sosial Ekonomi dan Kebijakan Pertanian. Bogor (2012).

3. A. Titin. Relasi: Jurnal Ekonomi. STIE Mandala Jember, Vol. 18 (2013). DOI: https://doi.org/10.31967/relasi.v18i0.11.

4. L. A. Wibawa. Fakultas Pertanian Universitas Mataram (2018).

5. N. Kaman and R. Muchjidin. Jurnal Pangan, Vol. 23 No. 1: 83 - 92. Perum Bulog (2014).

6. I. Mardian and A. Hipi. Prosiding Seminar Nasional. Balai Penelitian Tanaman Aneka Kacang dan Umbi, Malang (2016).

7. K. S. Indraningsih. Forum Penelitian Agro Ekonomi, Vol. 35 No. 2: 107-123 (2017).

8. M. Asaad and S. B. Sugiman. Jurnal Pengkajian dan Pengembangan Teknologi Pertanian, Vol. 3 No. 1 (2018).

9. T. Adisarwanto, Subandi and Sudaryono. Pusat Penelitian dan Pengembangan Tanaman Pangan, Kementerian Pertanian, Jakarta (2013).

10. F. Deswika and T. I. Noor. Jurnal Ilmiah Mahasiswa Agroinfo Galuh Vol. 4 No. 2 (2017).

11. C. Poniman, T. Sunardi and H. Pujiwati. Jurnal Ilmu-Ilmu Pertanian Indonesia (JIPI). 22(1): 38-44 (2020).

12. K. D. Puspita, D. W. Respatie, and P.Yudono. Vegetalika 6 (3): 24-36 (2017). 